\title{
$\begin{array}{lllll}\mathrm{F} & \mathrm{O} & \mathrm{R} & \mathrm{U} & \mathrm{M}\end{array}$ \\ $\begin{array}{llllllll}M & \longleftarrow & \mathrm{O} & \mathrm{D} & \mathrm{Y} & \mathrm{C} & \mathrm{H}\end{array}$
}

DAMIAN GAŁUSZKA

Uniwersytet Jagielloński, Instytut Socjologii

\section{POSTAWY ANTYPORNOGRAFICZNE WŚRÓD POLSKICH INTERNAUTÓW. WSTĘPNE UJĘCIE BADAWCZE}

Streszczenie: Artykuł stanowi jedną z pierwszych prób zwrócenia uwagi na relatywnie nowe zjawisko internetowych inicjatyw antypornograficznych. Są to strony i fora internetowe, zrzeszające internautów negatywnie nastawionych do pornografii, a często także masturbacji, które w ich mniemaniu mają destrukcyjne oddziaływać na wiele wymiarów życia. Zasadniczym celem nie jest jednak sam opis inicjatyw, ale ich odbioru wśród polskich internautów dzięki wykorzystaniu podejścia z zakresu etnografii wirtualnej. W praktyce oznaczało to analizę kilku publikacji internetowych i kilkuset komentarzy osób zaangażowanych lub zainteresowanych badanym zjawiskiem. W tekście są poruszone także etyczno-prawne problemy związane z prowadzeniem badań w Internecie na kontrowersyjne tematy.

Slowa kluczowe: wirtualne wspólnoty, samopomoc, pornografia, seks, NoFap.

\section{WPROWADZENIE}

Artykuł stanowi wstępną próbę przedstawienia wybranych reakcji polskich internautów na działalność ruchów antypornograficznych. Pod tym pojęciem kryje się wiele przedsięwzięć w postaci stron i for internetowych, a także kanałów na portalu YouTube, służących jako przestrzeń wyrażania opinii i samopomocy dla osób, które reprezentują negatywną opinię względem pornografii, a często chcą też uwolnić się od - ich zdaniem - negatywnego w skutkach korzystania z tego rodzaju treści oraz towarzyszącej temu masturbacji. Praktyka prowadzenia i angażowania się w cyfrowe grupy samopomocowe nie jest niczym nowym, jednocześnie rozwój technologiczny umożliwił poszerzenie zakresu stosowanych narzędzi wspierających, np. o rozbudowane fora dyskusyjne jak Reddit czy filmy na portalu YouTube. Opisany tu fenomen jest rozproszony na różnych witrynach internetowych. $\mathrm{Z}$ racji braku możliwości ujęcia wszystkich takich przedsięwzięć, a także ze względu na opisywane dalej kwestie etyczne i prawne, ten tekst skupia się na zagadnieniu recepcji inicjatyw antypornograficznych wśród polskich internautów w odniesieniu do obecnie najbardziej popularnej globalnie witryny, której działalność można określić mianem antypornograficznej- NoFap.com. Podstawą analizy są wyniki wyszukiwania w Google.

Adres do korespondencji: damian.galuszka@doctoral.uj.edu.pl, ORCID: https://orcid. org/0000-0001-5184-0737. 
Przedstawiana publikacja poza walorem poznawczym, ponieważ rozszerza wiedzę na do tej pory słabo rozpoznany w piśmiennictwie naukowym temat, zawiera omówienie kilku metodologicznych dylematów związanych z prowadzeniem badań w Internecie, które ujawniły się w procesie jej przygotowania. Mimo że jest to projekt z zakresu etnografii wirtualnej, socjologiczny i eksploracyjny, to na marginesie rozważań pojawiają się typowo psychologiczne zagadnienia uzależnień i ich konsekwencji, ponieważ są one kluczowe dla członków omawianych wspólnot, dlatego rzetelny ich opis nie może być pozbawiony tych wątków. Przy czym podkreślić należy, że z przeprowadzonej analizy wynika, że samo pojęcie uzależnienia określa zazwyczaj taki rodzaj zaangażowania $\mathrm{w}$ praktyki korzystania z pornografii i masturbacji, który zdaniem konkretnej osoby wiąże się z osobistymi negatywnymi konsekwencjami. Jest to więc subiektywne ujęcie tego tematu i z tego powodu publikacja ta nie zawiera próby zdefiniowania terminu „uzależnienie”, gdyż nie jest to ważne z perspektywy celów przeprowadzonego badania i samego artykułu. Autor ma nadzieję, że ten tekst zwróci uwagę innych badaczy - także odmiennych dyscyplin, a w szczególności psychologii - na do tej pory słabo rozpoznane zjawisko internetowych inicjatyw antypornograficznych, gdyż od kilku lat cieszą się one niesłabnącą popularnością, co potwierdzają wyniki w usłudze Google Trends czy statystyki tego rodzaju witryn internetowych. Opisywane tu przedsięwzięcia są także interesujące z perspektywy analiz napięć pomiędzy dominującymi zjawiskami (powszechność pornografii internetowej) a wytwarzanymi w kontrze do nich praktykami oporu (przedsięwzięcia antypornograficzne).

\section{SEKS A WIRTUALNE GRUPY SAMOPOMOCOWE - KRÓTKI RYS HISTORYCZNY}

Ważną cechą omawianych w tekście wirtualnych grup samopomocowych jest ich cyfrowy charakter. Są to przedsięwzięcia internetowe i opierają się na komunikacji zapośredniczonej komputerowo (computer-mediated communication, CMC). W efekcie gwarantują one przynajmniej częściową anonimowość, w zależności od preferencji kamuflującą podstawowe cechy społeczno-demograficzne internautów: płeć, wiek, miejsce zamieszkania, rasę, wyznanie, a także wizerunek, co może mieć znaczenie w przypadku prób poszukiwania wsparcia terapeutycznego, szczególnie dotyczącego delikatnych obszarów życia prywatnego (Szpunar, 2012).

Być może dlatego relatywnie wcześnie pojawiły się internetowe inicjatywy wspierające osoby z problemami w sferze seksualnej. Odwołując się do historii tego typu projektów, nie można zapomnieć o tradycyjnych grupach samopomocowych, które już w latach 90. XX w. próbowały zaadaptować niedawno skomercjalizowany Internet do własnych celów. Za przykład może tutaj posłużyć wspólnota SCA (ang. Sexual Compulsives Anonymous), w której ramach już w 1996 r. rozpoczęto realizację spotkań online, na co wskazuje archiwum witryny Sca-recovery.org (1996). O ile tego rodzaju grupy oparte na programie dwunastu kroków (Chanin, 2000) faktycznie otworzyły się na sferę online, o tyle w ich przypadku podstawową formą terapii jest osobiste zaangażowanie we wspólnotę (Wnuk, 2006). Wydaje się, że narzędzia cyfrowe: chaty online, telekonferencje, rozmowy na Skype, listy mailingowe itp., są tutaj dodatkiem do zasadniczo najważniejszych spotkań bezpośrednich i rzetelnej realizacji programu dwunastu kroków. 
W przypadku głównego przedmiotu zainteresowania, czyli internetowych przedsięwzięć antypornograficznych, oba aspekty nie odgrywają tak istotnej roli. Brakuje zarówno jednego i powszechnie uznanego programu postępowania, jak i regularnych spotkań w przestrzeni fizycznej (offline). Historycznie rzecz ujmując, powstanie omawianej tu szerzej strony NoFap.com poprzedziło kilka innych tego rodzaju witryn. Przykładami mogą być uruchomione odpowiednio w latach 1999, 2006, 2009 i 2010: no-porn.com, pornaddictioninfo.com, feedtherightwolf.org oraz yourbrainonporn. com. Istnieją także bardziej zindywidualizowane formy popularyzacji idei antypornograficznych w postaci nagrań wideo umieszczanych na portalu YouTube czy też blogów internetowych, a także fora internetowe, czego przykładem może być działające od 2004 r. polskie forum dyskusyjne onanizm.pl. O ile zasadniczy cel - czyli poprawa jakości swojego życia w sferze seksualnej i pochodnych w efekcie rezygnacji z pornografii - pozostaje podobny na wymienionych witrynach, tak nieco inne mogą być treści i narzędzia mające prowadzić do jego osiągnięcia, a także główne akcenty. Przykładowo forum onanizm.pl - przynajmniej oficjalnie - jest poświęcone raczej uzależnieniu od masturbacji, z kolei pozostałe witryny bardziej skupiają się na negatywnym oddziaływaniu konsumpcji pornografii, oferując nieco inne formy wsparcia (podręczniki, uczestnictwo we wspólnotach na forach lub grupach facebookowych, rozmowy $\mathrm{z}$ trenerem, prezentacje $\mathrm{w}$ formie wideo itp.).

\section{INICJATYWY ANTYPORNOGRAFICZNE A WSPÓŁCZESNA KULTURA}

Analizując przedsięwzięcia antypornograficzne, należy zwrócić uwagę na ich powiązanie z pewnymi cechami współczesnej kultury i nowymi technologiami. Wiadomo bowiem, że rozwój branży pornograficznej i rozpowszechnienie tego rodzaju treści wynikają zarówno z postępu technologicznego (nowe techniki filmu cyfrowego, powstanie internetowych usług płatniczych itp.), jak i zmianami o charakterze kulturowym (m.in. liberalizacja czy też ewolucja norm i zwyczajów). Pornografia jest coraz częściej relatywnie mocno wyeksponowanym składnikiem kultury popularnej, w której postępuje proces nasycenia treściami o charakterze seksualnym. Brian McNair (2004) pisze w tym kontekście o kulturze obnażania, w której seks, nagość i ekshibicjonizm są istotnymi składnikami przekazów medialnych w kapitalistycznych społeczeństwach końca XX w. i początków XXI w. Dla opisywanych tutaj mechanizmów istotny jest postęp w obrębie kultury materialnej. Z jednej strony przemiany technologiczne odegrały znaczącą rolę w procesie umasowienia dostępu do materiałów pornograficznych - jak zauważa Mirosław Filiciak (2007), znaczenie mają tu takie narzędzia jak: fotografia, konsumenckie kamery filmowe, magnetowidy czy wreszcie Internet z drugiej stanowią dziś także cyfrowe narzędzie autoterapii czy samopomocy.

Przykładem są opisywane dalej internetowe przedsięwzięcia antypornograficzne, które często pełnią nie tylko funkcję informacyjną, lecz także społeczną, dzięki działającym w ich obrębie wspólnotom wirtualnym. Popularyzacja pornografii może wiązać się też z wieloma negatywnymi zjawiskami o zróżnicowanym charakterze (fizycznym, psychoseksualnym, behawioralnym czy społecznym) (de Alarcón i in., 2019). Stanowią one treść całego systemu przekonań o negatywnym wpływie pornografii na jednostkowe i zbiorowe funkcjonowanie człowieka, co stanowi podstawę działalności internetowych inicjatywnych antypornograficznych. Jednocześnie wiele z podnoszonych w tych wspólnotach problemów zdaje się dotyczyć tylko mężczyzn, jak chociaż- 
by problemy z erekcją wywołane częstą masturbacją, co jest szerzej omówione w sformułowanych dalej wnioskach z własnej analizy. Zresztą podobnie męską perspektywę przyjął psycholog Philip Zimbardo, który od 2015 r., czyli premiery jego książki pod tytułem Man Disconnected: How technology has sabotaged what it means to be male (polskie wydanie nakładem PWN pt. Gdzie ci mężczyźni?), przekonuje, że nałogowe granie w gry wideo i konsumpcja pornografii stanowią główne przyczyny wielu problemów współczesnych mężczyzn.

Biorąc pod uwagę podjętą problematykę, warto wspomnieć o dwóch zagadnieniach, które mają charakter kulturowy i jednocześnie pojawiały się wyjątkowo rzadko w przeanalizowanych dyskusjach internetowych - jak się wydaje z powodu widocznej przewagi mężczyzn zaangażowanych w te rozmowy. Pierwszym i chyba najmniej dyskusyjnym problemem jest ekspozycja dzieci i młodzieży na treści dla dorosłych, które stanowią jedno z głównych zagrożeń dla najmłodszych internautów (Pyżalski, Zdrodowska, Tomczyk, Abramczuk, 2018). Źródeł tego zagrożenia doszukiwać się można w słabych zabezpieczeniach stron z pornografią (zazwyczaj ograniczają się one do deklaracji samego internauty), niskiej świadomości i niedostatecznego zaangażowania ze strony opiekunów czy też braku należytej edukacji w zakresie bezpiecznego korzystania z zasobów cyfrowych oraz zdrowia seksualnego. Na marginesie warto jednak wspomnieć, że kwestia dostępu do pornografii jest zagadnieniem wymagającym rozważenia różnych, społecznie istotnych wartości. Chodzi tu przecież o konieczność ochrony dzieci, ale też swobody obywatelskie, które zdaniem niektórych komentatorów mogą być ograniczane w sytuacji wprowadzenia systemu faktycznej weryfikacji wieku internauty. Opisywane rozwiązania wprowadzono niedawno w Wielkiej Brytanii, gdzie każdy obywatel, chcący skorzystać z serwisów dla dorosłych, musi podać swój unikalny „AgeID” - jest to kod wydawany na podstawie dokumentu tożsamości czy danych z karty płatniczej. Jak się wydaje, brytyjski ustawodawca wziął jednak pod uwagę obawy części obywateli, dlatego alternatywną formą uzyskania kodu jest zakup specjalnej 16-dniowej karty w sklepie, podczas którego sprzedawca ma weryfikować wiek kupującego (Grygiel, 2019).

Drugim ważnym, a jednocześnie słabo obecnym w przeanalizowanych dyskusjach wątkiem są sposoby ukazywania kobiecego ciała i roli kobiet w pornografii. W filmach dla dorosłych panie zazwyczaj są przedstawiane w zgodzie z męskimi preferencjami estetycznymi (Melosik, 2010). Taka perspektywa bywa też określana mianem męskiego spojrzenia (ang. male gaze), w którym bierna kobieta jest wystawiana na spojrzenie aktywnego obserwatora-mężczyzny, który czerpie z tej sytuacji swoistą przyjemność czy satysfakcję (Mulvey, 1975). Prowadzi to m.in. do reprodukowania niekorzystnego wizerunku kobiet - rzekomo zawsze uległych i chętnych do realizacji często nierealistycznych scenariuszy z produkcji pornograficznych. Pewną odpowiedzią na ten dominujący w branży wzorzec są próby tworzenia „feministycznych” wersji filmów, czego przykładem mogą być wysiłki Eriki Lust i podobnych jej twórczyń (Saul, 2016). Jednakże tego rodzaju próby popularyzacji kobiecej perspektywy na sceny filmowanego seksu ciągle stanowią raczej margines całego przemysłu treści dla dorosłych i nie mają większego wpływu na główny nurt.

\section{NOFAP - KRÓTKIE OMÓWIENIE}

Jedną z najbardziej popularnych obecnie inicjatyw antypornograficznych, co potwierdza analiza zapytań wykonana przy użyciu usługi Google Trends oraz statystyki popularności z serwisu Alexa, jest kryjąca się pod zastrzeżoną nazwą NoFap witryna i to- 
warzyszące jej forum dyskusyjne. Jak piszą twórcy strony, nazwa NoFap to połączenie angielskiego słowa no (nie) oraz wyrażenia fap, które jest onomatopeją wykorzystywaną w komiksach na oznaczenie dźwięków towarzyszących masturbacji (NoFap.com, 2016). Mimo sugerującej to nazwy, oficjalnym celem ruchu NoFap nie jest zachęcanie do całkowitej rezygnacji z masturbacji, a wspieranie internautów w procesie rezygnacji z sięgania po materiały pornograficzne i realizacji różnorodnych celów związanych z dobrostanem w zakresie zdrowia seksualnego (Rhodes, 2017). Te ostatnie, zdaniem założyciela witryny Alexandra Rhodesa (2017), mają ogromny wpływ na funkcjonowanie znacznego odsetka internautów, głównie z uwagi na wyjątkowo powszechny dostęp do tego rodzaju treści. W swoim wystąpieniu z 2017 r. na konferencji amerykańskiego Narodowego Centrum ds. Przypadków Wykorzystywania Seksualnego (National Center on Sexual Exploitation), powołuje się on na relacje (dzienniki) prowadzone przez forumowiczów, skąd ma wyłaniać się obraz ludzi, u których wieloletnia konsumpcja internetowej pornografii doprowadziła do sytuacji, kiedy są oni bardziej zainteresowani „pikselami”, czyli filmami, a nie swoimi partnerami seksualnymi. Odwołując się w swojej wypowiedzi do bliżej nieokreślonych badań, Rhodes przedstawia w swoim wystąpieniu liczne konsekwencje konsumpcji pornografii na życie jednostek oraz ich relacje z innymi. Jest to ważny wątek dla wielu ruchów antypornograficznych, ponieważ badania - szczególnie z zakresu szeroko pojętych neuronauk - są nie tylko podstawą mitu założycielskiego (jak w przypadku projektu NoFap, co opisuję dalej), lecz także dostarczają argumentów uzasadniających konieczność ograniczania konsumpcji pornografii i jej negatywnego wpływu na życie ludzi.

Wyróżniającą się tu postacią jest Gary Wilson, założyciel innej witryny antypornograficznej Your Brain on Porn (yourbrainonporn.com), który od lat rozwija bazę tekstów naukowych (pojedynczych badań i metaanaliz z różnych dyscyplin), ukazujących destrukcyjny wpływ pornografii na wiele kontekstów życia jednostkowego i społecznego (Wilson, 2019). Powoływanie się na źródła naukowe ma też na celu ukazanie, że problem nie rozgrywa się jedynie na płaszczyźnie moralnej (każdy może mieć osobisty pogląd na pornografię i też nie wszyscy przedstawiciele omawianych tu inicjatyw głoszą konieczność całkowitej rezygnacji z jej oglądania) czy religijnej (wiele wspólnot, w tym NoFap, utrzymuje względnie równy dystans do wszystkich opcji światopoglądowych), ale dotyczy też realnych i empirycznie udowodnionych skutków oglądania materiałów dla dorosłych, którym należy przeciwdziałać. Oczywiście w ten sposób następuje też legitymizacja podejmowanych działań i głoszonych poglądów na pornografię. Jednocześnie zasadnym wydaje się pytanie, na ile osoby bez wykształcenia kierunkowego - czyli jak się zdaje większość internautów zaangażowanych w ruchy antypornograficzne - są w stanie rzetelnie ocenić $\mathrm{i}$ właściwie zinterpretować wyniki często skomplikowanych i niejednoznacznych w swojej wymowie projektów badawczych. Zachodzi tu uzasadniona obawa o możliwość powstania nieuprawnionych wniosków.

Początki witryny NoFap.com są związane z amerykańskim portalem społecznościowym Reddit. Idea NoFap jest inicjatywą oddolną. W 2011 r. jeden z użytkowników Reddita opublikował wpis pod tytułem „TIL when men don't masturbate for 7 days their testosterone levels increase by 45.7\%” („Poziom testosteronu wzrasta o 45,7\% u mężczyzn, którzy nie masturbują się przez 7 dni”), będący odnośnikiem do badań zrealizowanych na chińskim uniwersytecie w Hangzhou, które sugerują istnienie pozytywnego związku pomiędzy ograniczeniem ejakulacji a wzrostem poziomu testosteronu u mężczyzn (por. Jiang, Jiang, Zou, Shen, 2003). Wpis wywołał dyskusję, na którą złożyło się ponad 2000 komentarzy (Reddit, 2011), a po jakimś czasie rozważania przeniosły się do innych 
wątków na Redditcie. Dyskutowano m.in. na temat wyzwania, które miałoby polegać na powstrzymywaniu się od wytrysku przez $7 \mathrm{dni}$. W trakcie rozmów pojawiła się opinia, że czasowa rezygnacja z masturbacji może być atrakcyjną techniką motywacyjną. W efekcie tych rozważań Alexander Rhodes - ówcześnie użytkownik Reddita i późniejszy fundator strony NoFap.com - postanowił założyć subforum (to znaczy wydzielony tematycznie fragment portalu Reddit) o nazwie NoFap, co nastąpiło w czerwcu $2011 \mathrm{r}$. Aktualnie to subforum zrzesza ponad 600000 fapstronautów. Dla porównania w kwietniu 2016 r. było ich o ponad połowę mniej, bo 200000.

Początkowym założeniem inicjatywy NoFap nie była samopomoc, a organizowane challenge, czyli wyzwania - tygodniowe i miesięczne programy abstynencji od masturbacji. Jednak poza podejmowaniem wyzwań, użytkownicy Reddita dość szybko zaczęli dzielić się swoimi przemyśleniami i problemami związanymi z życiem seksualnym, czego efektem było rozszerzenie społeczności o osoby zainteresowane procesem wychodzenia z uzależnienia od pornografii, co w slangu wspólnoty przyjęło miano rebootingu, czyli swego rodzaju resetowania mózgu na podstawie czasowej (zazwyczaj 30, 90 dni) i całkowitej rezygnacji z materiałów pornograficznych, a niekiedy także masturbacji i seksu z inną osobą (Jensen, 2016). Ma to na celu - jak twierdzą zwolennicy tego poglądu - przywrócenie chemicznej równowagi mózgu. Alexander Rhodes (2017) wprost nazywa rezygnację z konsumowania internetowej pornografii jedną z najbardziej seks-pozytywnych decyzji, jaką można podjąć w życiu. Wydaje się, że z taką tezą zgodziłoby się wielu przedstawicieli wspólnot opowiadających się przeciwko pornografii. Jednocześnie różne, wcześniej wspominane, witryny związane z ideą abstynencji od pornografii, a także towarzyszące im fora dyskusyjne, przynajmniej częściowo odnoszą się do innego zakresu informacji i publikowanych doświadczeń swoich użytkowników.

W przypadku inicjatywy NoFap forum jest przestrzenią do dyskusji nad samą ideą i kwestiami pochodnymi związanymi z życiem i rozwojem seksualnym człowieka, m.in.: uzależnieniem od pornografii, problematycznymi zachowaniami seksualnymi, samorozwojem, samotnością i relacjami międzyludzkimi. Szczególnie interesujący jest dział, w którym forumowicze publikują swoje - często wielomiesięczne i bardzo intymne - dzienniki (Rhodes, 2017), a także inny fragment forum, przeznaczony do poszukiwania tzw. partnerów wspierających (ang. accountability partner), czyli fapstronautów, którzy są chętni na prywatne rozmowy i wzajemną pomoc w parze (Jensen, 2016). W przywołanym wcześniej wystąpieniu Alexander Rhodes (2017) wspomina też o narzędziach, które pomagają fapstronautom w ich zmaganiach. Bez wchodzenia w szczegóły forum, wymienić tutaj można dostępne zarówno na opisanym już subforum Reddita, jak i stronie NoFap tzw. Emergency Motivation Tool/Emergency Web App. Jest to specjalna strona, która wyświetla motywacyjne artykuły, grafiki czy filmy z wybranej przez użytkowników kategorii, co ma im pomóc w sytuacjach kryzysowych, gdy odczuwają potrzebę masturbacji bądź skorzystania z materiałów pornograficznych (Mains, 2018). Na projekt NoFap składają się też profil na Facebooku, konto na Twitterze oraz kanał z filmami na YouTube.

\section{CEL I METODA}

W celu wypracowania wniosków dotyczących recepcji wybranych inicjatyw antypornograficznych wśród polskich internautów niezbędne było wyselekcjonowanie polskich stron internetowych, na których w mniejszym lub większym stopniu odnoszo- 
no się do witryny lub idei NoFap. Pomocna w tym celu okazała się wyszukiwarka Google, która pozwala na wyszukiwanie wzajemnie powiązanych stron internetowych. W efekcie udało się wytypować ponad 70 różnych adresów - zarówno tradycyjnych blogów, komercyjnych tytułów prasowych, jak i odnośników do filmów - na których pojawia się wzmianka o inicjatywie stanowiącej przedmiot zainteresowania. Do analizy zrealizowanej w okresie wakacyjnym 2019 r. włączono treść głównych wpisów lub filmów, jak również towarzyszących im komentarzy internautów. W ten sposób odniesiono się do faktycznej dyskusji i wymiany poglądów pomiędzy internautami, nie ograniczając się tylko do opinii autora głównej wypowiedzi. Takie podejście pozwoliło na odtworzenie praktyk dyskursywnych, które oddziałują na poglądy internautów zaangażowanych w badane dyskusje (van Dijk, 2001), chociaż tylko do pewnego stopnia, ponieważ wiele wpisów internautów (szczególnie w komentarzach) jest pozbawionych tak ważnego dla analizy kontekstu wypowiedzi (Charmaz, 2009). Można jednak przyjąć, że są to ograniczenia do zaakceptowania zważywszy na wstępny i eksploracyjny charakter badania (Babbie, 2003).

\section{PRAWNO-ETYCZNE ASPEKTY BADAŃ W INTERNECIE}

Jak zasygnalizowano wcześniej, badania w Internecie, a w szczególności te dotyczące zjawisk intymnych lub kontrowersyjnych, generują wiele wątpliwości natury etycznej i prawnej. Przestrzeń cyfrowa stanowi od kilkudziesięciu lat interesujący poznawczo obszar ludzkiej działalności, w którym próbuje się prowadzić różnego rodzaju przedsięwzięcia naukowe. Wiele z tradycyjnych metodologii i technik badawczych zostało dostosowanych do badań sfery Internetu, czego przykładem jest prezentowany projekt, wpisujący się w założenia etnografii wirtualnej. Jest to podejście, które odwołuje się do modeli badawczych, znanych tradycyjnej etnografii i charakteryzuje się próbą ujęcia i holistycznego opisania interakcji społecznych zachodzących w cyfrowych wspólnotach (Given, 2008). Perspektywę etnografii wirtualnej skonkretyzował Robert Kozinets (2012) w swojej koncepcji netnografii, stanowiącej spójną metodologię prowadzenia badań nad internetowymi interakcjami, w której są opisane wszystkie najważniejsze etapy procesu badawczego: przygotowanie planu, uzyskanie dostępu do wspólnoty, zbieranie i analiza danych, przepracowanie wątpliwości etycznych oraz ewaluacja.

Inne, bardziej ilościowe i statystyczne ujęcia to analizy z zakresu big data, w których wykorzystuje się moc współczesnych komputerów i zaawansowanych narzędzi analitycznych do poszukiwania zazwyczaj ukrytych wzorców w ogromnych zbiorach danych, generowanych przez internautów (Sagiroglu, Sinanc, 2013).

Bez względu na samo podejście metodologiczne, w mocy pozostają prawne i etyczne aspekty prowadzenia badań. Jedną z powszechnie przyjętych zasad jest ta o nienarażaniu uczestników na jakiekolwiek straty i nieprzyjemności (Oppenheim, 2004). Jednocześnie okazuje się, że prowadzenie analiz w Internecie wymaga ponownego rozważenia prawno-etycznych aspektów działalności naukowej (Jemielniak, 2019). Zdaniem Dariusza Jemielniaka (2019), który powołuje się na innych badaczy, nie wypracowano jeszcze powszechnie obowiązujących standardów prowadzenia badań online, a najważniejsze obszary refleksji dotyczą anonimowości, prywatności, świadomej zgody, własności oraz poufności danych i wymagają one każdorazowej, jak i pogłębionej refleksji etycznej badacza. 
Na pierwszy plan wysuwa się tu tak podstawowa kwestia, jak zapewnienie anonimowości badanych. Współcześnie nie tylko profil na portalu społecznościowym, ale nawet pseudonim internauty może wskazywać na jego faktyczną tożsamość. Kolejne zagadnienie to prywatność, która odnosi się do rodzaju danych publikowanych w sieciach internetowych i wątpliwości, na ile są one prywatne lub też publiczne. Pod rozwagę należy też brać konieczność zapytania potencjalnych badanych o chęć udziału w przedsięwzięciu. Podobnie jak w pozostałych najważniejszych zagadnieniach etycznych, w odniesieniu do świadomej zgody także można spotkać się z różnymi podejściami. Od restrykcyjnego Roberta Kozinetsa (2012), którego zdaniem badacz powinien zawsze się ujawnić i dążyć do uzyskania świadomej zgody od wszystkich zaangażowanych w proces badawczy, przez różniące się od siebie wytyczne stowarzyszeń naukowych, po ujęcia przestrzeni Internetu jako całkowicie publicznej, gdzie zgoda badanych jest potrzebna jedynie w sytuacjach, gdy badacz wchodzi w bezpośrednią z nimi relację (Sugiura, Wiles, Pope, 2017). Problematyczne jest też ustalenie własności danych. Niekiedy publikacja treści na portalu internetowym wiąże się z przeniesieniem części praw na właściciela serwisu. Jednocześnie pierwotni autorzy zachowują często niematerialne prawa do uznania autorstwa, co może stać w sprzeczności z koniecznością ochrony ich tożsamości oraz prywatności (Jemielniak, 2019). Jest to jeden z tych dylematów, który trudno rozwiązać ogólnym zaleceniem, chociaż jak sugeruje Jemielniak, zawsze należy trzymać się zasady nadrzędnej, czyli ochrony badanych przed faktycznymi i potencjalnymi konsekwencjami upublicznienia ich tożsamości (2019). Wreszcie pochylić się trzeba nad problemem poufności danych. Jest to zagadnienie, które wykracza poza sam proces badawczy i dotyczy także bezpieczeństwa wykorzystywanych przez badacza urządzeń, programów czy nośników (Jemielniak, 2019). Okazuje się, że samo popularne maskowanie imion i nazwisk w nagraniach i ich transkrypcjach to za mało. Zasadniczo chodzi o to, aby gromadzone dane przetwarzać i gromadzić w sposób, który minimalizuje potencjał ich nieautoryzowanego wykorzystania przez osoby lub podmioty trzecie - szczególnie, jeśli są to materiały zawierające wrażliwe dane na kontrowersyjne tematy.

Innym wymiarem omawianej problematyki jest prawo do prowadzenia aktywności naukowej na stronie lub forum i wykorzystania w celach badawczych opublikowanych tam treści. Wiele stron czy for dyskusyjnych nie odnosi się w regulaminach do kwestii prowadzenia badań naukowych. W takich przypadkach, jak się zdaje, badacz ma większą swobodę w zakresie wykorzystania tego rodzaju materiałów poprzez odwołanie do instytucji dozwolonego użytku (w systemach common law jest to fair use) czy prawa cytatu. Inaczej kwestia ta wygląda w sytuacji, gdy na interesującej stronie czy forum sformułowano konkretne zapisy warunkujące możliwość prowadzenia badań. Tak jest w przypadku inicjatywy NoFap. Zarówno na samej witrynie NoFap. com, jak i na towarzyszącym jej forum dyskusyjnym są dostępne regulaminy, które zakazują prowadzenia jakichkolwiek analiz naukowych bez pisemnej zgody administracji. Dość restrykcyjnie opisano też reguły wykorzystywania zastrzeżonych nazwy i logo witryny, a także pojęcia określającego członka tej wspólnoty, czyli „fapstronauty”. W efekcie tych ograniczeń nie było możliwości prowadzenia bezpośredniej analizy strony NoFap.com i jej forum. Pomimo podjętej próby kontaktu z twórcą nie udało się uzyskać zgody na przeprowadzenie obserwacji i analizę danych zastanych. Te trudności wpłynęły na przyjęty schemat badawczy, w efekcie przedstawione wcześniej opisy inicjatywy powstały na podstawie źródeł pośrednich oraz nagrania publicznej prezentacji jej twórcy - Alexandra Rhodesa - podczas której wykłada on swoje przekonania, 
stanowiące podstawę stworzonego przez niego przedsięwzięcia. Natomiast właściwe badanie było przeprowadzone wyłącznie na polskich stronach internetowych, gdzie wspomina się o witrynie czy wspólnocie NoFap.

Biorąc pod uwagę wszystkie opisane wątpliwości, przyjęto strategię, zgodnie z którą nie kopiowano danych ze źródłowych witryn, a przedstawiana we wnioskach narracja ma charakter zagregowany i wytworzony na podstawie lektury publikowanych tekstów i systematycznego notowania własnych przemyśleń. Te noty nie zawierają nazw własnych - adresów stron, pseudonimów autorów itp. - na podstawie których można zidentyfikować konkretnego internautę. Dodatkowo w tym artykule nie ma żadnych bezpośrednich cytatów, nazw odwiedzonych stron internetowych, a samo przedstawienie wniosków z przeprowadzonej analizy jest przygotowane w sposób możliwie zgeneralizowany, co utrudnia jednoznaczną identyfikację konkretnego internauty. Oczywiście ogranicza to zarówno potencjał analityczny autora, jak i wyjaśniający samego tekstu, jednak wydaje się, że taki poziom ochrony internautów jest niezbędny z uwagi na charakter podjętej problematyki. Podobnie zainteresowanych szczegółami witryny NoFap.com i jej forum odsyła się do źródła, ponieważ przedstawiane w publikacji opisy są ograniczone do niezbędnego minimum i stworzone na podstawie publicznej wypowiedzi twórcy tej strony oraz źródeł pośrednich. Oznacza to, że NoFap.com i jej forum nie zostały poddane systematycznej analizie, ponieważ nie zezwalają na to ich regulaminy w sytuacji braku pisemnej zgody administratorów.

\section{WYNIKI I DYSKUSJA}

Analiza stron internetowych ze względu na rodzaj opublikowanej treści pozwala na wyprowadzenie dwóch ich kategorii: publicystycznych i prywatnych. Te pierwsze to w głównej mierze artykuły opublikowane na internetowych portalach konkretnych tytułów prasowych (zarówno zupełnie świeckich, jak i tych o charakterze religijnym). Druga kategoria zawiera wpisy na blogach (dominują blogi poświęcone procesowi wychodzenia z uzależnienia od pornografii, ale pojawiają się też strony o samorozwoju, relacjach damsko-męskich czy lifestylowe dla mężczyzn), posty na forach internetowych (bardzo różnych: ogólnotematycznych, powiązanych ze zdrowiem psychicznym, dla graczy czy mężczyzn), filmy na platformach streamingowych, grafiki na stronach z memami, podcasty czy też komentarze pod w zasadzie wszystkimi przywołanymi rodzajami publikacji. Cały przeanalizowany zbiór tekstów nie był zbyt rozbudowany (10 dłuższych artykułów, kilkaset komentarzy, kilka rozmów na forach dyskusyjnych), co umożliwiło przyjęty sposób analizy danych, o czym piszę we fragmencie poświęconym dylematom etyczno-prawnym. Zasadniczy wniosek jest taki, że inicjatywa NoFap nie wygenerowała zbyt dużego zainteresowania na polskich portalach publicystycznych, gdyż artykułów, w których to hasło się pojawia (co warte podkreślenia, niekoniecznie w wiodącej roli), było zaledwie kilka. Poświęcono je zazwyczaj charakterystyce subforum Reddita, strony lub forum dyskusyjnego NoFap.com, a także sylwetce ich twórcy Alexandra Rhodesa.

Jednocześnie większy poziom zainteresowania dało się zauważyć wśród „zwykłych” internautów - tworzących wpisy na blogach, posty na forach czy filmy odnoszące się do idei NoFap. Tu dominowały osobiste relacje i refleksje, skupiające się na procesie - jak często to określali sami zainteresowani - uzależnienia od pornografii i masturbacji, a następnie etapie „resetowania” mózgu dzięki uczestnictwu w wyzwaniach NoFap. 
Większość dyskusji prywatnych da się wpisać w następujący schemat:

- przedstawienie idei NoFap - nie zawsze w odniesieniu do samej strony NoFap.com, jej forum czy subforum r/NoFap na portalu Reddit; niekiedy pojęcie „nofap” bywa traktowane nie jako - co ważne zastrzeżona - nazwa własna, a ogólnie przyjęty termin opisujący praktykę wstrzemięźliwości od masturbacji czy oglądania pornografii;

- określenie własnego stosunku do tego przedsięwzięcia - zazwyczaj afirmatywnego, ponieważ często osoby inicjujące dyskusje zdążyły już same zaangażować się we własne wyzwanie, chociaż nie zawsze było to efektem lektury strony NoFap.com czy jej forum dyskusyjnego, źródłami inspiracji są często inne (opisane wcześniej) strony antypornograficzne, blogi czy filmy i to pomimo odwoływania się do terminu „nofap”, podobnie jest z terminem „fapstronauta” - w przeanalizowanej próbce tekstów bardzo rzadko jest on przywoływany i polscy rozmówcy prawie się z nim nie identyfikują;

- opisanie korzyści z uczestnictwa w wyzwaniu - co znamienne, bardzo rzadko wspomina się o negatywnych aspektach tego przedsięwzięcia, także formułowane wnioski nie zawsze są tożsame, a niekiedy nawet sprzeczne w doświadczeniu różnych internautów.

Najmocniej wybijające się cechy tych dyskusji to nadreprezentacja mężczyzn i typowo męskich problemów. Zazwyczaj przywołuje się trudności z erekcją podczas prób obycia stosunku, ale też kłopoty na wcześniejszych etapach znajomości, takie jak niemożność nawiązania bądź utrzymania relacji z kobietą czy rzekomy niski poziom męskich hormonów wywołany nadmierną masturbacją. Wpisów kobiet zaangażowanych we własne wyzwania praktycznie nie było, a w pojedynczych przypadkach internautki problematyzowały zagadnienie, zwracając uwagę na kobiecą perspektywę, chociaż bez pogłębionych rozważań.

Inna cecha omawianego dyskursu to jego polaryzacja. Zazwyczaj dyskutanci są zwolennikami lub przeciwnikami idei NoFap i rzadko natknąć się można na zdystansowane opinie, co w połączeniu z wysoką subiektywnością wyrażanych tez prowadzi niekiedy do ostrej i wulgarnej wymiany zdań. Ta subiektywność wyraża się przede wszystkim tym, że wiele opisów, szczególnie korzyści z udziału w wyzwaniu, ma charakter zupełnie indywidualny i w zasadzie trudno mierzalny - np. zmiany nastrojów w wybranych odcinkach czasowych czy zwiększone zainteresowanie ze strony napotykanych kobiet. Co więcej, komentujący często inaczej opisywali własne reakcje na wyzwanie. Niektórzy wskazywali na wyjątkowo szybkie pojawienie się pozytywnych efektów, inni natomiast zwracali uwagę, że przez pewien czas reakcja organizmu jest negatywna, pojawiają się np. bóle głowy, obniżony nastrój, rozdrażnienie czy nawet bóle ciała (np. jąder).

Te wnioski - zarówno pozytywne, jak i negatywne - dotykają ważnych i skomplikowanych obszarów ludzkiej egzystencji, dlatego niepokoi obecny w przeanalizowanych dyskusjach redukcjonizm. Polega on na tym, że sprowadza się wiele fizycznych, psychicznych i emocjonalnych korzyści do jednej przyczyny - udziale w wyzwaniu i abstynencji od masturbacji lub pornografii. Niestety w przeanalizowanych rozmowach zazwyczaj nie problematyzowano własnego zaangażowania w wyzwanie, co można częściowo tłumaczyć swego rodzaju ich ideologizacją.

Ta ideologizacja polega na tym, że pomimo rzadko ujawnianych motywacji religijnych (które dominowały głównie w artykułach opublikowanych na stronach o religijnej proweniencji - zasadniczo tylko katolickiej), wielu dyskutantów opowiadało się jednoznacznie za konkretną wizją człowieka i pornografii. Zwykle jest to wizja 
sprawczego mężczyzny, który opiera się pokusom i jest stawiany w opozycji do „nieudacznika”, który nie panuje nad własnymi popędami i zależnością od pornografii - najczęściej przedstawianej jako źródło samych negatywnych treści i oddziaływań. W zależności od motywacji autora wypowiedzi można spodziewać się odmiennego zestawu określeń. Przykładowo w narracjach osadzonych w kontekście religijnym spotkać można podniosły język i wyrazy przywodzące na myśl bohaterów toczących heroiczną walkę z istotnym i niezwykle wyniszczającym przeciwnikiem (uzależnienie od masturbacji i pornografii są przedstawiane jako uwłaczające i totalnie destrukcyjne). Oczywiście używane są też takie określenia jak grzech.

Kolejna wyróżniająca się cecha przeanalizowanego dyskursu to fetyszyzacja liczb oraz momentu „upadku” czy też powrotu (ang. relapse) do masturbacji lub oglądania pornografii. Internauci biorący udział w wyzwaniach przywiązują relatywnie dużą uwagę do cyfr określających długość wyzwania. Dodatkowo wielu skrupulatnie liczy dni od ostatniego „upadku”, bijąc kolejne osobiste rekordy trwania w postanowieniu. $Z$ jednej strony wynika to z „pełnych” okresów wyzwań (7, 30, 90 dni itd.) - które mają formę uznaniową i pomimo częstych odwoływań do opracowań naukowych są raczej efektem subiektywnej decyzji, reprodukowanej później przez kolejnych naśladowców - ale też przekonania, że pewne zmiany w mózgu (np. „regulacja” receptorów dopaminowych) wynikające z jego neuroplastyczności zachodzą dopiero po jakimś czasie, a konkretna liczba dni czy miesięcy jest często odmienna w zależności od osoby, która się na ten temat wypowiada. Pewien negatywny wzór da się też zauważyć w odniesieniu do zjawiska relapsu czy też „upadku” - osoby, które w trakcie wyzwania sięgają po materiał pornograficzny lub masturbują się dość często, przedstawiają to w kategoriach znaczącej porażki. Podkreślają szereg negatywnych odczuć z tym związanych, a także obaw o cofnięcie spodziewanego pozytywnego efektu wstrzemięźliwości. W skrajnych przypadkach ów schemat podnoszenia się po kolejnym upadku odtwarza się przez miesiące czy nawet lata, co może być wyjątkowo frustrujące.

Zastanawia też, jak się wydaje, pozorna naukowość dyskursu. Często dyskutanci odwoływali się do lepiej lub gorzej opisanych doniesień rzekomo naukowych, by potwierdzić swój tok rozumowania. W niektórych wypowiedziach stawiano też w roli ekspertów czy autorytetów osoby niekoniecznie profesjonalnie i naukowo związane z danym zagadnieniem. Ujawnia się tu problem rzetelności źródeł informacji oraz ich właściwej interpretacji. Co więcej, rozpiętość poglądów jakoby uzasadnionych naukowo rozciąga się od przekonania, że zbyt częsta masturbacja i nałogowe oglądanie pornografii radykalnie zmieniają biochemię mózgu, przez ich wpływ na dobrostan psychiczny i różnie rozumiane poczucie męskości, po tezy, że częste orgazmy u mężczyzn powodują znaczną utratę minerałów i witamin z organizmu. Abstrahując od wspominanej zdolności komentujących do weryfikacji powielanych sformułowań, zastanowić się trzeba, czy nie miał racji Zygmunt Bauman, mówiąc, że pewnie „nie ma już tezy tak absurdalnej, żeby nie dało jej się podeprzeć wynikami badań naukowych przeprowadzonych w uznanych ośrodkach" (Żakowski, 2004). Absolutnie nie chodzi tu o to, że tezy kryjące się za ideą NoFap czy innymi ruchami antypornograficznymi nie mają rzeczywistej naukowej wartości. Warto jednak zwrócić uwagę na zaobserwowany w przeanalizowanej próbce tekstów schemat reprodukcji tez uznawanych za naukowe, ale zazwyczaj w sposób uznaniowy, subiektywny i bez należytego opisu, umożliwiającego rzeczywistą ich weryfikację.

Niepokojące może być też tworzenie - jak się zdaje - nieuprawnionych analogii pomiędzy doświadczeniami różnych internautów. Powszechny wzorzec rekomendacji 
zakłada, że to co pomogło jednej osobie, z pewnością pomoże też innym z ich subiektywnym - tj. bez profesjonalnej diagnozy - poczuciem uzależnienia od masturbacji czy pornografii. Chodzi tu zarówno o różnice indywidualne (w wymiarze zdrowia fizycznego, psychicznego, osobowości itp.), środowiskowe (inna sytuacja rodzinna, towarzyska, czasem odmienna kultura), jak i światopoglądowe (różne motywacje, wewnętrzne systemy przekonań), które w znacznym stopniu mogą modyfikować osobiste doświadczenia wynikające z udziału w wyzwaniu NoFap. Takie uproszczone analogie, w połączeniu z zadziwiająco rzadko podnoszoną w dyskusjach kwestią wizyt u faktycznych specjalistów - psychologów, seksuologów czy psychiatrów - mogą narażać internautów na niepotrzebne cierpienia związane z brakiem spodziewanych efektów, co też kilka razy było podniesione w różnych rozmowach. Dwojaki rodzaj argumentów - z badań naukowych oraz społecznego dowodu potwierdzenia w postaci doświadczeń osób zaangażowanych w wyzwania - wydaje się przekonujący, chociaż w zasadzie można by je traktować jako dowody anegdotyczne i zazwyczaj nieweryfikowalne (np. pogląd, że abstynencja od pornografii i masturbacji wpływa pozytywnie na powodzenie wśród kobiet). W pojedynczych przypadkach rozmówcy problematyzowali te kwestie i zastanawiali się, czy dostrzegane pozytywne efekty nie są jedynie wynikiem siły autosugestii.

Z przedstawionego opisu wynika, że odbiór idei NoFap wśród polskich internautów jest dość problematyczny w jednoznacznej ocenie. Sporo tu uproszczeń, subiektywnych (czasami dość radykalnych) interpretacji, a niekiedy także niedopowiedzeń. Z pewnością można jednak dostrzec kilka pozytywnych efektów prowadzonych w Internecie rozmów na ten temat. Sama dyskusja i uczestnictwo w niej, a następnie udział w wyzwaniu, stwarzają szansę na otwarcie się na zmianę postrzeganego jako negatywny nawyku i zastąpienie go innymi. Z przeanalizowanych wypowiedzi wynika, że chodzi o raczej te pozytywne: sport, pasje, naukę nowych umiejętności, powrót do hobby, większą wydajność w pracy itp. Co więcej, być może te dysputy w pozytywny sposób mogą wpływać na podejście mężczyzn do kobiet i relacji damsko-męskich. Kilka razy powtórzył się motyw zmiany nastawienia na mniej uprzedmiatawiające i bardziej partnerskie - przynajmniej wśród tych internautów, którzy poddają się narracjom ukierunkowanym na odbudowę relacji damsko-męskich, a nie jedynie samorozwój. Ta druga narracja może prowadzić do przekonania o odbudowie własnej męskości, związanej być może ze wzorcem casanovy (niektóre z przeanalizowanych stron są poświęcone zdobywaniu kobiet). Wreszcie przeniesienie uwagi z filmowych aktorów na prawdziwych ludzi może powodować większe otwarcie na kontakty (w tym seksualne) z drugim człowiekiem, co powinno pozytywnie oddziaływać na odbudowę relacji społecznych - szczególnie u tych osób, które poświęcały najwięcej czasu na oglądanie filmów pornograficznych czy masturbację. Jednakże zadać sobie trzeba też pytanie, czy ci najbardziej potrzebujący nie uzyskaliby lepszego wsparcia u profesjonalistów lub w tradycyjnych grupach wsparcia dla osób uzależnionych. Niestety wydaje się, że w większości przypadków zaangażowanie w wirtualne wyzwania stanowi wyłączającą alternatywę, a nie działanie towarzyszące poszukiwaniom profesjonalnej pomocy.

\section{PODSUMOWANIE}

Intymny charakter poruszanych przez internautów problemów, w powiązaniu ze świadomością etyczno-prawnych dylematów oraz niechęcią administratorów do udzielania zgód na prowadzenie badań, stanowią istotną przeszkodę metodologicz- 
ną w pogłębionym opisie podjętej problematyki. Należy zastanowić się nad schematem badawczym zjawiska ruchów antypornograficznych czy wirtualnych wspólnot samopomocowych powstających w ich ramach. Być może rozwiązaniem jest rezygnacja $z$ badań obserwacyjnych (wirtualna etnografia na forach internetowych) na rzecz przedsięwzięć sondażowych, w przypadku których łatwiej uzyskać jednoznaczną i świadomą zgodę respondentów na przekazanie informacji o intymnej sferze ich cyfrowego i fizycznego życia. Przy odpowiedniej konstrukcji kwestionariusza nie zachodzi tu aż tak duże niebezpieczeństwo identyfikacji konkretnego internauty, jak w przypadku analiz danych zastanych na stronach internetowych. Innym interesującym w perspektywie kolejnych badań wątkiem jest dominacja mężczyzn i typowo męskich problemów w ramach opisanych inicjatyw. Wartościowym byłoby sprawdzenie, na ile płeć różnicuje zaangażowanie i schemat partycypacji w tego rodzaju przedsięwzięciach. Wreszcie bez odpowiedzi pozostaje pytanie o faktyczny wpływ uczestnictwa w internetowych ruchach antypornograficznych na psychofizyczną kondycję ich uczestników, ze szczególnym uwzględnieniem sfery seksualnej. Chociaż wielu zwolenników internetowych wyzwań widzi bezpośrednie i pozytywne konsekwencje swoich działań, to ciągle brakuje pogłębionych i rzetelnych badań nad faktyczną korelacją czy przyczynowością.

Interesujące poznawczo byłoby tu porównanie tradycyjnej terapii grupowej, eksperckiej (wizyty u seksuologa) oraz internetowej (aktywność w ruchach lub wspólnotach antypornograficznych). Jest to jednak zadanie dla interdyscyplinarnego zespołu badawczego, a ten tekst stanowi jedynie wstępną próbę zwrócenia uwagi badaczy na tę problematykę. Wydaje się, że kolejne badania empiryczne są niezbędne, ponieważ $\mathrm{w}$ tej materii obserwujemy ciągły progres technologiczny i powiązane z nim zmiany społeczne. Skoro „zwykła”, dwuwymiarowa pornografia potrafi generować tak znaczące problemy w życiu ludzi, to już należy podejmować analizy nad efektami wdrożeń, chociażby technologii gogli wirtualnej rzeczywistości (ang. virtual reality, VR) w branży pornograficznej, które gwarantują zupełnie nowy poziom zaangażowania i zanurzenia widza w obserwowany obraz (por. Herman, 2015).

\section{BIBLIOGRAFIA}

Alarcón de, R., de la Iglesia, J.I., Casado, N.M., Montejo, A.L. (2019). Online porn addiction: What we know and what we don't - A systematic review. Journal of Clinical Medicine 8.1. https:// www.mdpi.com/2077-0383/8/1/91/ htm.

Babbie, E. (2003). Badania spoteczne w praktyce. Warszawa: WN PWN.

Charmaz, K. (2009). Teoria ugruntowana. Praktyczny przewodnik po analizie jakościowej. Warszawa: WN PWN.

Chanin, A. (2000). Twelve-Step Programs as an Adjunct to Psychotherapy and Psychopharmacology. Primary care companion to the Journal of clinical psychiatry,
2(4), 130-133. http://europepmc.org/articles/PMC181125/.

Dijk van, T. (2001). Badania nad dyskursem. Tegoż. Dyskurs jako struktura $i$ proces. Warszawa: WN PWN.

Filiciak, M. (2007). Od pornografii do sfery publicznej, czyli co łączy seks i demokrację. Kultura Wspótczesna, 2, 245-250.

Given, L.M. (red.). (2008). The Sage encyclopedia of qualitative research methods. Vol 2. London: Sage Publications.

Grygiel, B. (2019). Wlk. Brytania ogranicza dostęp do pornografii. Nowe prawo uderza $w$ wolność stowa? https:// www.focus.pl/artykul/wielka-brytania- 
wprowadza-ograniczenia-porno-bardzoniepokojace.

Herman, B. (2015). Porn industry looks to virtual reality technology for next boom. International Business Times. http://www.ibtimes.com/porn-industrylooks-virtual-reality-technology-nextboom-1802704.

Jemielniak, D. (2019). Socjologia Internetu. Warszawa: Wydawnictwo Naukowe Scholar.

Jensen, K.T. (2016). Internet Gutter: Nofap Nation. https://www.geek.com/culture/ internet-gutter-nofap-nation-1667523/.

Jiang, M., Jiang, X., Zou, Q., Shen, J. (2003). A research on the relationship between ejaculation and serum testosterone level in men. Journal of Zhejiang University science, 4(2), 36-240.

Kozinets, R. (2012). Netnografia. Badania etnograficzne online. Warszawa: WN PWN.

Mains, D. (2018). Six apps you need to conquer pornography and masturbation. https://www.stand-magazine.com/6-appspornography-and-masturbation/.

McNair, B. (2004). Seks, demokratyzacja pożadania i media, czyli kultura obnażania. Warszawa: Muza.

Melosik, Z. (2010). Tożsamość, ciato i wtadza $w$ kulturze instant. Kraków: Impuls.

Mulvey, L. (1975). Visual pleasure and narrative cinema. Screen, 3, 6-18.

Oppenheim, A.N. (2004). Kwestionariusze, wywiady, pomiary postaw. Poznań: Zysk i Ska.

Reddit. (2011). TIL when men don'tmasturbate for 7 days their testosterone levels increase by $45.7 \%$. https://www.reddit.com/r/todayilearned/comments/i514e/til_when_ men_dont_masturbate_for_7_days_ their/.
Rhodes, A. (2017). Pornography Interrupts Evolution. https://vimeo.com/234740658.

Sca-recovery.org. (1996). Experimental Online Meeting. https://web.archive.org/ web/19961114133252/http://sca-recovery.org/online.html.

Pyżalski, J., Zdrodowska, A., Tomczyk, Ł., Abramczuk, K. (2019). Polskie badanie EU Kids Online 2018. Najważniejsze wyniki $i$ wnioski. Poznań: Wydawnictwo Naukowe UAM.

Saul, H. (2016). Erika Lust: The feminist adult film maker changing the face of porn. The Independent. https://www. independent.co.uk/news/people/erika-lust-the-feminist-adult-film-makerchanging-the-face-of-porn-a7083331. html.

Sagiroglu, S., Sinanc, D. (2013). Big Data: A Review, Collaboration Technologies and Systems (CTS). 2013 International Conference on Digital Object Identifier, 42-47.

Sugiura, L., Wiles, R., Pope, C. (2017). Ethical challenges in online research: Public/private perceptions. Research Ethics, 13(3-4), 184-199.

Szpunar, M. (2012). Nowe-stare medium. Internet między tworzeniem nowych modeli komunikacyjnych a reprodukowaniem schematów komunikowania masowego. Warszawa: Wydawnictwo IFiS PAN.

Wilson, G. Research. https://www.yourbrainonporn.com/research/.

Wnuk, M. (2006). Zaangażowanie w ruch samopomocy a poczucie jakości życia osób uzależnionych od alkoholu. Alkoholizm i Narkomania, 19(4), 357-368.

Żakowski, J. (2004). Jak jesteśmy manipulowani. Polityka. https://www.polityka.pl/tygodnikpolityka/spoleczenstwo/12166,1,jak-jestesmy-manipulowani.read. 


\section{ANTI-PORN ATTITUDES AMONG POLISH INTERNET USERS. AN INITIAL RESEARCH}

Abstract: This article is one of the first attempts to draw attention to the relatively new phenomenon of the Internet antiporn initiatives. These initiatives embody as websites and internet forums that gather Internet users who are negatively oriented towards pornography and often also masturbation, which in their opinion have destructive effects on many dimensions of life. However, the main aim of the article is not to describe the initiatives themselves, but to illustrate their recognition among Polish Internet users by using the virtual ethnography approach. In practice, this came down to the analysis of several online publications and several hundred comments of people involved or interested in the studied phenomenon. The publication also covers ethical and legal problems related to conducting Internet research on controversial topics.

Keywords: virtual communities, self-help, pornography, sex, NoFap. 